\title{
An overview on the potential of geopolymers for concrete infrastructure rehabilitation
}

\author{
F. Pacheco-Torgal ${ }^{\mathrm{a}, *}$, Z. Abdollahnejad $^{\mathrm{a}}$, S. Miraldo ${ }^{\mathrm{b}}$, S. Baklouti ${ }^{\mathrm{c}}$, Y. Ding $^{\mathrm{d}}$ \\ ${ }^{a}$ University of Minho, C-TAC Research Centre, Guimarães, Portugal \\ ${ }^{\mathrm{b}}$ University of Aveiro, CICECO, Aveiro, Portugal \\ ${ }^{\mathrm{C}}$ University of Sfax, Sfax, Tunisia \\ ${ }^{\mathrm{d}}$ Dalian University of Technology, State Key Laboratory of Coastal and Offshore Engineering, Dalian, China
}

\section{H I G H L I G H T S}

- Geopolymers can be used as sealers for concrete structures.

- Geopolymers could replace epoxy adhesives in FRP retrofitting.

- Geopolymers are potential low toxicity, cost-efficient lining materials.

\section{A R T I C L E I N F O}

\section{Article history:}

Received 24 May 2012

Accepted 8 July 2012

\section{Keywords:}

Concrete structures

Sealers

Patch repair

FRP strengthening

Concrete pipes

Trenchless rehabilitation

Geopolymers

\begin{abstract}
A B S T R A C T
Infrastructure rehabilitation represents a multitrillion dollar opportunity for the construction industry. In USA alone the rehabilitation needs are estimated to exceed 1.6 trillion dollars over the next 5 years. Since the majority of the existent infrastructures are concrete based this means that concrete infrastructure rehabilitation is a hot issue to be dealt with. Besides the sooner concrete deterioration is tackled the lower are the rehabilitation costs. This paper provides a literature review on concrete repair materials, highlighting the current problems face by them. It covers concrete surface treatments, patch repair and FRP strengthening. The case of trenchless rehabilitation of concrete sewage pipelines is also discussed. The potential of geopolymers to overcome those limitations is analyzed.
\end{abstract}

(c) 2012 Elsevier Ltd. All rights reserved.

\section{Introduction}

Worldwide infrastructure rehabilitation costs are staggering. For example in the USA the needs are estimated to be over 1.6 trillion dollars over the next 5 years, where about $27 \%$ of all highway bridges are in need of repair or replacement, and the corrosion deterioration cost due to deicing and sea salt effects is estimated at over 150 billion dollars [1]. In the USA alone, it is estimated that annual investments of up to $\$ 21$ billion is required to provide adequate infrastructure wastewater. It is also estimated that the annual operation and maintenance costs associated with wastewater infrastructure to be in excess of $\$ 25$ billion [2].

In the European Union nearly 84,000 reinforced and prestressed concrete bridges require maintenance, repair and strengthening with an annual budget of $£ 215 \mathrm{M}$, and that estimate does not

\footnotetext{
* Corresponding author.

E-mail address: torgal@civil.uminho.pt (F. Pacheco-Torgal).
}

include traffic management cost [3]. Many of the degraded concrete structures were built decades ago when little attention was given to durability issues [4]. The importance of durability in the context of eco-efficiency of construction and building materials has been rightly put by Mora [5], when he stated that increasing concrete durability from 50 to 500 years would mean a reduction of its environmental impact by a factor of 10 . Materials with low durability require frequent maintenance and conservation operations or even its integral replacement, being associated with the consumption of raw materials and energy. The "Law of Fives" cited by Delatte [6] states that $\$ 1$ spent on design and construction is equivalent to $\$ 5$ spent as damage initiates and before it propagates, $\$ 25$ once deterioration has begun to propagate, and \$125 after extensive damage has occurred. This concept highlight the importance acting the sooner the possible to prevent concrete structures to reach that level when extensive damage has occurred and the rehabilitation costs grew exponentially. In that context to assess if current repair materials are effective in addressing concrete 
infrastructure rehabilitation needs is of paramount importance. R4 Investigations in the field of geopolymers had an exponential increase after the research results of Davidovits [7] who developed and patented binders obtained from the alkali-activation of metakaolin, having named it after the term "geopolymer" in 1978. For the chemical designation of the geopolymer Davidovits suggests the name "polysialates", in which Sialate is an abbreviation for aluminosilicate oxide. The sialate network is composed of tetrahedral anions $\left[\mathrm{SiO}_{4}\right]^{4-}$ and $\left[\mathrm{AlO}_{4}\right]^{5-}$ sharing the oxygen, which need positive ions such as $\left(\mathrm{Na}^{+}, \mathrm{K}^{+}, \mathrm{Li}^{+}, \mathrm{Ca}^{++}, \mathrm{Na}^{+}, \mathrm{Ba}^{++}\right.$, $\mathrm{NH}_{4}^{+}, \mathrm{H}_{3} \mathrm{O}^{+}$) to compensate the electric charge of $\mathrm{Al}^{3+}$ in tetrahedral coordination (after dehydroxilation the aluminum changes from coordination 6 (octahedral) to coordination 4 (tetrahedral). The Polysialate has the following empiric formulae:

$\mathrm{M}_{n}\left\{-\left(\mathrm{SiO}_{2}\right)_{z}-\mathrm{AlO}_{2}\right\}_{n}, \mathrm{wH}_{2} \mathrm{O}$

in which $n$ is the degree of polymerization, $z$ is 1,2 or 3 , and $M$ is an alkali cation, such as potassium or sodium, generating different types of Poly(sialates) (Fig. 1). According to Davidovits, geopolymers are polymers because they transform, polymerize and harden at low temperature. But they are also Geo-polymers, because they are inorganic, hard and stable at high temperature and also noninflammable. Over the last years several authors have reported research in a large number of aspects related to geopolymers such as: dependence of the nature of source materials (alkali-activated binders synthesised from calcined sources show a higher compressive strength than from raw materials) $[9,10]$, immobilization of toxic metals [11-13], reaction mechanisms and hydration products [14-18], the role of calcium in geopolymerization [19-21], the development of lightweight building materials [22], durability issues [23-25] and even LCA [26,27]. However, very few studies in the geopolymer field have addressed the rehabilitation of deteriorated concrete structures. One possible explanation for the aforementioned gap relates to the fact that most geopolymer research groups belong to the field of materials science and not to the field of civil engineering. This shows the importance of a review paper that could highlight the importance of this area.

\section{Concrete structures}

\subsection{Surface treatments}

Concrete durability means above all minimizing the possibility of aggressive elements to enter the concrete, under certain

Poly(sialate) Si:Al=1 (-Si-O-Al-O-)
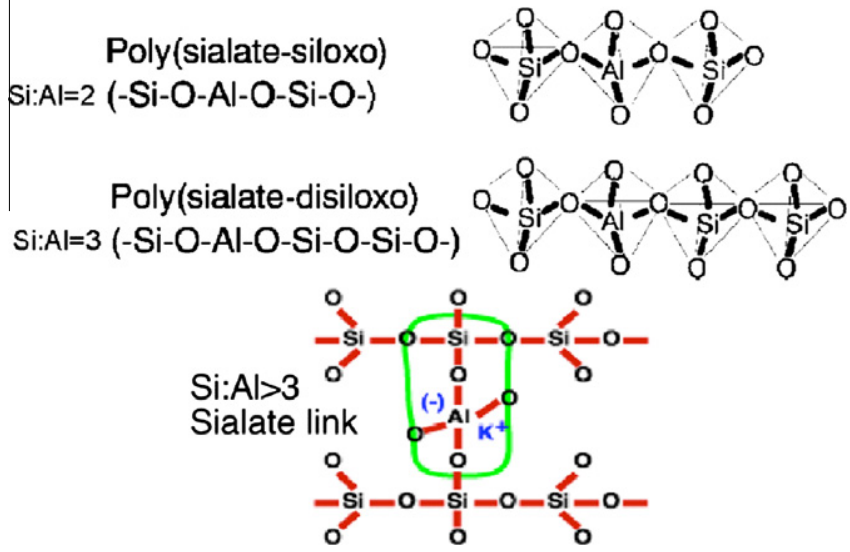

Fig. 1. Poly(sialates) structures [8]. environmental conditions for any of the following transport mechanisms: permeability, diffusion or capillarity (Fig. 2). The use of concrete surface treatments with waterproofing materials (also known as sealers) to prevent the access of aggressive substances is an important way of contributing to concrete durability. The most common surface treatments use polymeric resins based on epoxy, silicone (siloxane), acrylics, polyurethanes or polymethacrylate. Bijen [29] mentioned that the epoxy resins have low resistance to ultraviolet radiation and polyurethanes are sensitive to high alkalinity environments. On the other hand although some waterproof materials are effective for a particular transport mechanism (diffusion, capillarity, permeability) cannot be for another. Medeiros \& Helene [30] used a water repellent material based on silane-siloxane noticing that although it is effective to reduce the water absorption by capillarity of concrete (reduced from 2 to 7 times), it only managed to achieve a reduction of the chloride diffusion from $11 \%$ to $17 \%$ and also failed to prevent the access of water by permeability. Balaguru [31] study the use of geopolymer as a protective coating material for transportation infrastructures. Those authors mentioned that geopolymeric matrix cures to a glassy texture and hence organic paints do not adhere to geopolymer coated surfaces making them also graffiti resistant. Unlike organic coatings geopolymer coatings are permeable to vapor pressure and thus do not delaminate from the parent surface [32]. Other investigations [33] showed that geopolymer coatings are durable (Fig. 3) even in field conditions, given an example of a geopolymeric coating application under saltwater exposure conditions in Rhode Island with 9 years old. More recently, Zhang et al. $[34,35]$ mentioned that the use of geopolymers for sealing the concrete surface can be a more effective technique than the organic polymers used so far. Nevertheless, they mention a shrinkage problem that could be solved by appropriate addition of PP fiber and $\mathrm{MgO}$ as expansion agent as well as careful curing at an early age.

\subsection{Patch repair}

The patch repair method is widely used to restore the original conditions of the concrete structures [36,37]. In order to ensure structural compatibility and also compatibility with the concrete substrate patch repair mortars must meet certain requirements (Table 1, Fig. 4). The application of the patch repair mortar is preceded by cleaning the concrete surface to remove pieces of degraded concrete. Moreover, as the roughness of the concrete substrate affects the performance of most patch repair mortars, it becomes necessary to artificially increase its roughness, regardless of the cleaning operation. A rapid adhesion to the concrete substrate is therefore a fundamental property of patch repair mortars,

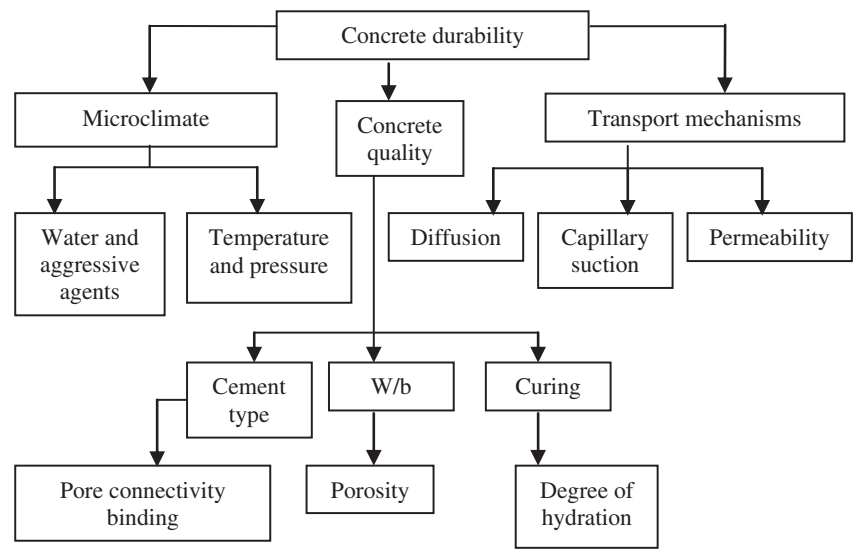

Fig. 2. Concrete durability [28]. 


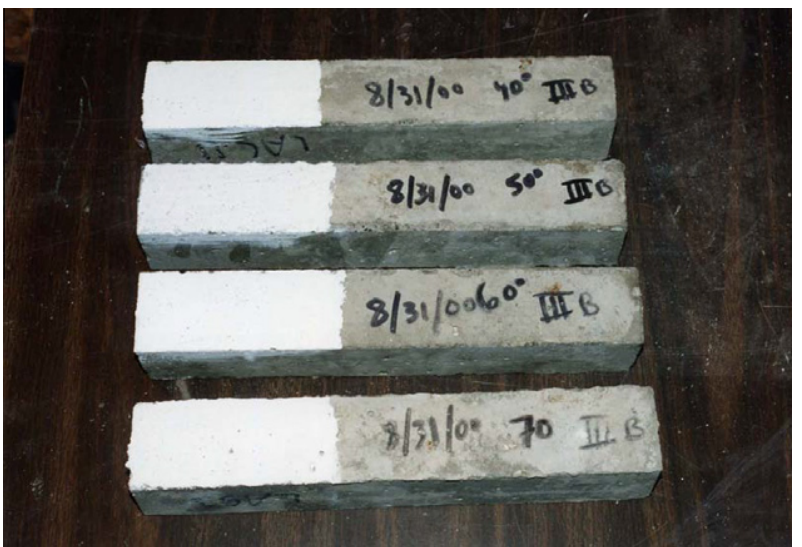

Fig. 3. Concrete prisms coated with geopolymer and exposed to running water [33].

Table 1

Structural compatibility - general requisites for repair mortars [38].

\begin{tabular}{|c|c|}
\hline Properties & $\begin{array}{l}\text { Relation between the repair mortar (Rp) } \\
\text { and the concrete substrate }(\mathrm{Cs})\end{array}$ \\
\hline $\begin{array}{l}\text { Strength in compression, } \\
\text { tension and flexure }\end{array}$ & $\mathrm{Rp} \geqslant \mathrm{Cs}$ \\
\hline $\begin{array}{l}\text { Modulus in compression, } \\
\text { tension and flexure }\end{array}$ & $\mathrm{Rp} \sim \mathrm{Cs}$ \\
\hline Poissońs ratio & Dependent on modulus an type of repair \\
\hline $\begin{array}{l}\text { Coefficient of thermal } \\
\text { expansion }\end{array}$ & $\mathrm{Rp} \sim \mathrm{Cs}$ \\
\hline $\begin{array}{l}\text { Adhesion in tension and in } \\
\text { shear }\end{array}$ & $\mathrm{Rp} \geqslant \mathrm{Cs}$ \\
\hline $\begin{array}{l}\text { Curing and long term } \\
\text { shrinkage }\end{array}$ & $R p \geqslant C s$ \\
\hline Strain capacity & $\mathrm{Rp} \geqslant \mathrm{Cs}$ \\
\hline Creep & $\begin{array}{l}\text { Dependent on whether creep causes } \\
\text { desirable or undesirable effects }\end{array}$ \\
\hline Fatigue performance & $\mathrm{Rp} \geqslant \mathrm{Cs}$ \\
\hline
\end{tabular}

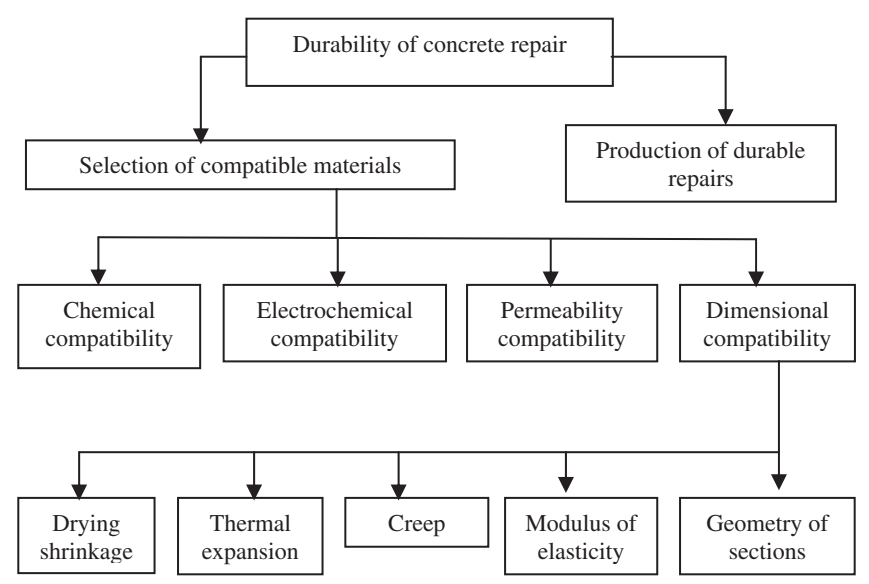

Fig. 4. Factors that influence of the durability of repair mortars [38].

allowing that the structure is back into service. Most patch repair mortars fall into two categories, the mortars based on organic binders (epoxy resin or polyester) or those based on inorganic binders like Portland cement. Murray [39] mentioned that latexmodified patch repair mortars are used widely and successfully. However, the latter are more cost effective and less toxic, being commercially as a pre-pack mixture of Portland cement, aggregates, silica fume, fibers and other additives. Recent investigations in the field of geopolymers reveal a third category of mortars with

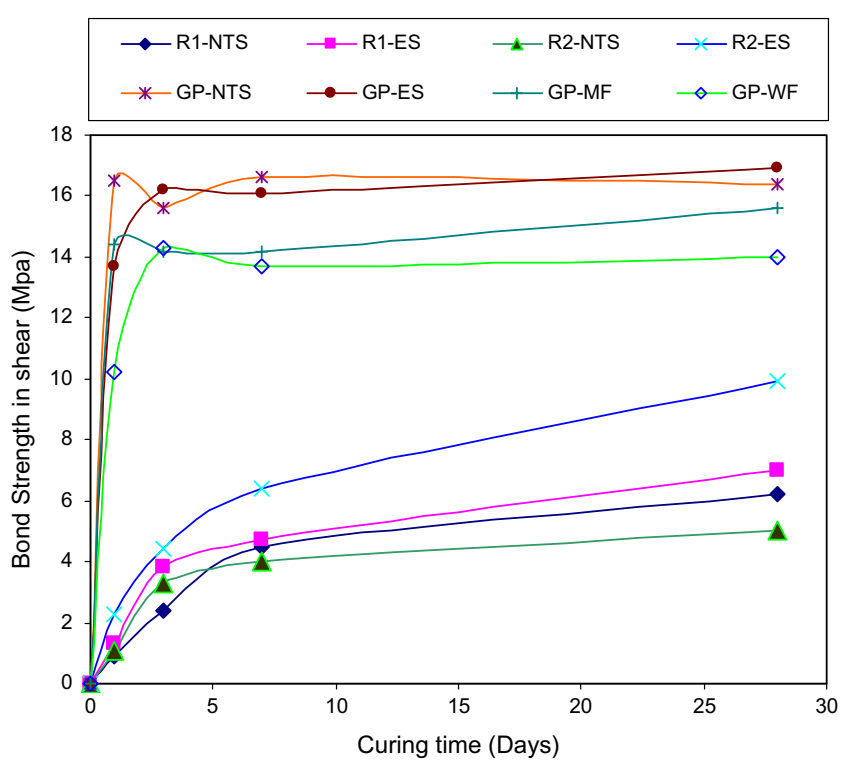

Fig. 5. Adhesion strength using the "slant-shear" test [40].

high potential to be used in the field of concrete patch repair [19]. Since the adhesion to the concrete substrate is a crucial property of the repair mortars, some results related to the comparison between geopolymer mortars and commercial products for the repair of concrete structures are presented. The adhesion strength was evaluated using the slant shear test. The slant shear test uses square prisms made of two halves, one of the concrete substrate and one of the repair material, tested under axial compression. The adopted geometry for the slant shear specimens was a $50 \times 50 \times 125 \mathrm{~mm}^{3}$ prism with an interface line at $30^{\circ}$ to the vertical. Bond strength was calculated by dividing the maximum load at failure by the bond area and was obtained from an average of four specimens determined at the ages of $1,3,7$, and 28 days of curing. In order to increase the specific surface of the concrete substrate an etching procedure was carried out. The concrete surface was immersed in a $5 \%$ hydrochloric acid solution for $5 \mathrm{~min}$ and then carefully washed to ensure the removal of $\mathrm{CaCl}_{2}$ which results from the reaction between $\mathrm{HCl}$ and $\mathrm{Ca}(\mathrm{OH})_{2}$. The specimens were named after the repair materials and concrete substrate surface treatments. Specimens using concrete substrate repaired with commercial product R1 with and with no surface treatment were named respectively, R1-ES (Etched surface) and R1-NTS (No treatment surface). Similarly, when the geopolymer based binder was used to bond the two halves they were named GP - ES and GP NTS respectively. Slant specimens with substrate surface treatment as cast against metallic formwork, and as cast against wood formwork were also used repaired with geopolymeric binder and were named, GP-MF and GP-WF respectively. The results of the effect of the several repair solutions on average adhesion strength are shown in Fig. 5. It can be seen that the specimens repaired with the geopolymeric mortar present the high adhesion strength́s even at early ages. Specimens repaired with geopolymeric mortar with 1 day curing have higher bond strength than specimens repaired with current commercial products after 28 days curing. Specimens repaired with the geopolymeric mortar appear to be influenced not by the chemical treatment in sawn concrete surface substrates, but by the use of concrete surfaces as cast against formwork. Those kinds of surfaces are rich in calcium hydroxide but lack exposed coarse aggregates which could contribute to improve bond strength due to silica dissolution from the aggregate surface. The strength performance of commercial repair products is very dependent on curing time and this constitutes a serious setback when 


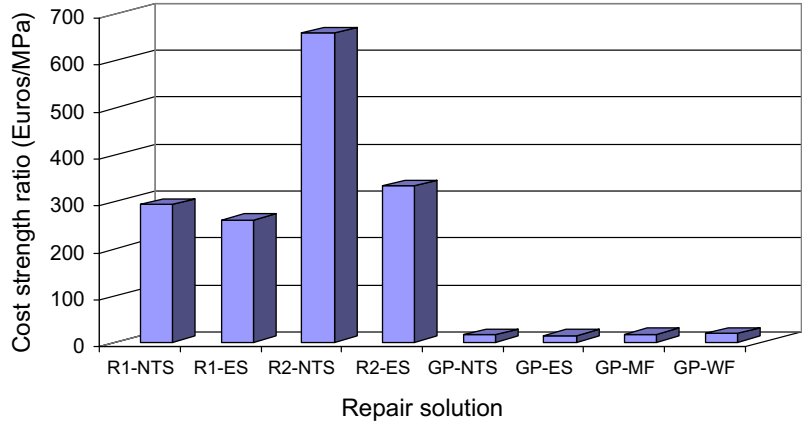

Fig. 6. Cost to strength ratio after 28 days curing according to repair solution [40].

early bond strength is required. The results show that bond strength using repair product R2 is clear influenced by the surface treatment. Even if the current commercial repair materials had the same mechanical performance of the geopolymeric binder, the cost of the cheapest one (R1) is still 6, 9 times higher than the geopolymeric binder. When comparing the cost to bond strength ratio the differences are even higher, with the cost of the cheapest solution with current commercial repair products (R1-ES) being 13, 8 times higher than the geopolymer repair mortar (see Fig. 6).

\subsection{Structural retrofitting using FRP}

Different techniques can be used in rehabilitation works of concrete structures. The most used are the strengthening with fiber reinforced polymer-FRP developed first in Japan [41-43] and the increase of elements sections with new concrete [44]. The bond between the concretes, steel and FRP is usually made with epoxy adhesives. An important property of the epoxy adhesives is the glass transition temperature $(\mathrm{Tg})$. It is the temperature above which polymers change from relatively hard and elastic to viscous, rubbery-like behavior. Due to this, some recommendations have suggested that epoxy resins should not be used at temperatures above their $\mathrm{Tg}$ and further that the selected materials should have a $\mathrm{Tg}$ of at least $20^{\circ} \mathrm{C}$ above the maximum expected service temperature. According to Gamage et al [45] both experimental results and finite elements calculations show that epoxy adhesives should not be exposed at temperatures above $70^{\circ} \mathrm{C}$, in order to maintain the integrity of the strengthened elements. Past investigations [46] confirm that epoxy adhesives exhibit poor behavior when subjected to increased temperatures, causing important bond deterioration. This means that adhesive materials like geopolymers known to possess high stability at high temperature, can be an alternative to epoxy resins. Balaguru et al. [33] showed that concrete samples coated with carbon reinforced geopolymer did not degrade after 100 cycles of wetting and drying. Recent investigations [47] related to geopolymeric mortars used as adhesive for CFRP revealed that the adhesion strength between CFRP and geopolymer mortars was lower than expected. This could be due to the fact that the composition of the geopolymeric mortars was not optimized and also to the fact that the CFRP used was not prone to this kind of application.

\section{Trenchless rehabilitation of concrete sewage pipelines}

Concrete sewage pipes are prone to sulfuric acid attack produced by sulfur oxidizing bacteria [48] thus requiring replacement or rehabilitation actions. Since the 1980s that several trenchless technologies allows for pipeline rehabilitation without surface excavation and traffic disruption. Trenchless technologies use different types of liners, such as slip liners, cured-in-place liners, and formed-in-place pipe liners [49]. Current lining materials are based on Portland cement, epoxy, polyurethane, polyurea and
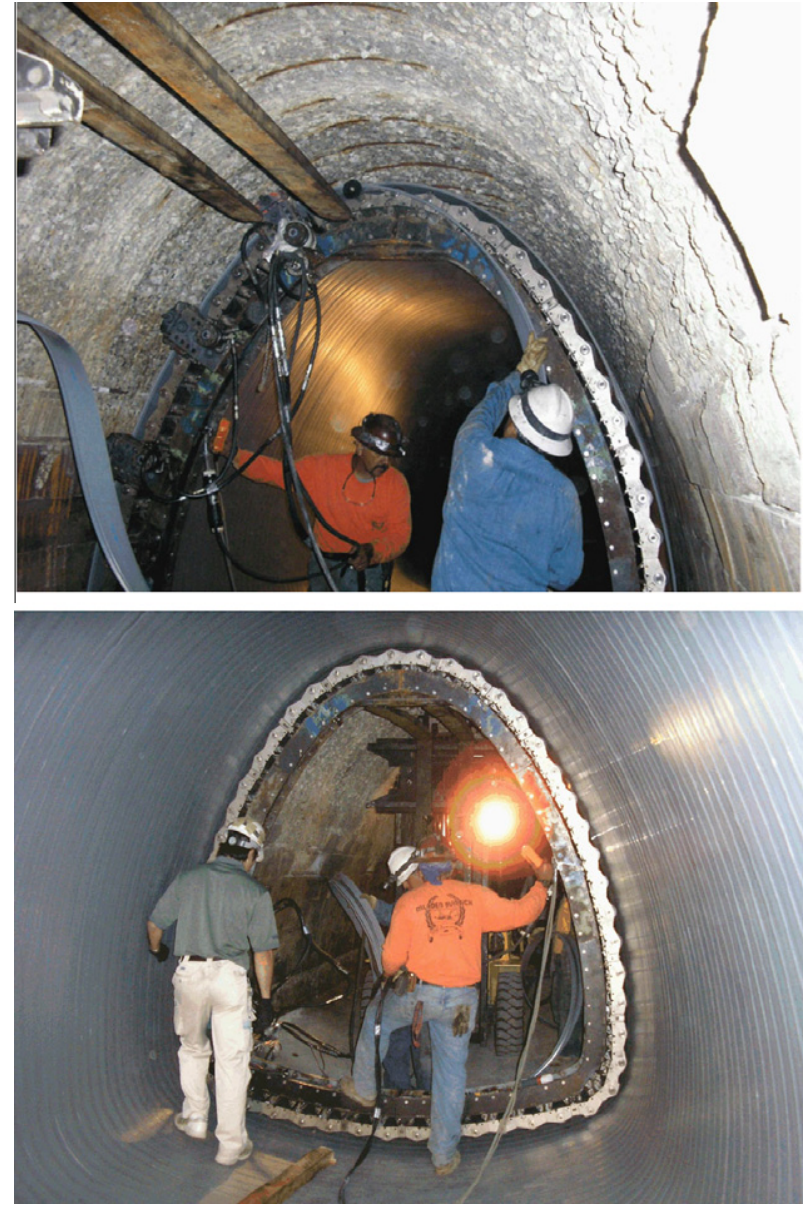

Fig. 7. Rehabilitation of a reinforced concrete pipeline sewer with a PVC liner

polyurea/polyurethane hybrids [50]. Polyurethane is obtained from the isocyanates, known worldwide for its tragic association with the Bhopal disaster. The production of polyurethane also involves the production of toxic substances such as phenol and chlorofluorocarbons. Burtner et al. [51] described the rehabilitation of a $4632 \mathrm{~m}$ long large concrete sewer with a polyvinyl chloride (PVC) liner (Fig. 7). PVC is a thermoplastic polymer, obtained from the polymerization of vinyl chloride monomer, which in turn is obtained from petroleum and chlorine. Chlorine is associated to the production of dioxins and furans that are extremely toxic and also bio-cumulative. Several scientist groups already suggest that chlorine industrial based products should be prohibited [52]. Besides recently the European Union recently approved the Regulation (EU) 305/2011 related to the Construction Products Regulation (CPR) that will replace the current Directive 89/106/CEE, already amended by Directive 1993/68/EEC, known as the Construction Products Directive (CPD). A crucial aspect of the new regulation relates to the information regarding hazardous substances [53]. Since geopolymer performance [54-56], concerning the resistance to acid attack, is far better than that of Portland cement, this means that this materials could be an alternative low toxicity, cost-efficient lining material. Some investigations have already been conducted in this field, however, so far it covered only the mixture development phase and the resistance to acid attack $[57,58]$.

\section{Conclusions}

Worldwide infrastructure rehabilitation costs are staggering. Since the majority of the existent infrastructures are concrete 
based this means that concrete infrastructure rehabilitation is a hot issue to be dealt with. The use of sealers to prevent the access of aggressive substances is an important way of contributing to concrete durability. Sealers based on epoxy resins have low resistance to ultraviolet radiation and polyurethanes are sensitive to high alkalinity environments. Although some sealers are effective for a particular transport mechanism cannot be for another. Unlike organic based sealers geopolymer are permeable to vapor pressure and thus do not delaminate from the parent surface, however, they may present shrinkage problems. The patch repair method is widely used to restore the original conditions of the concrete structures. Most patch repair mortars fall into two categories, the mortars based on organic binders or those based on inorganic binders like Portland cement. The former allow for a rapid repair and has no shrinkage problems, as to the latter they are more cost effective and less toxic. Geopolymers are even more cost effective and due to its stability at high temperature, they can be an alternative to epoxy resins for structural retrofitting using FRP. They can also be used as low toxicity, cost-efficient lining material for trenchless rehabilitation of concrete sewage pipelines. New investigations are needed related to the use of geopolymers on the field of concrete infrastructure rehabilitation.

\section{References}

[1] Davalos JF. Advanced materials for civil infrastructure rehabilitation and protection. New York: Seminar at the Citty College of New York; 2012

[2] O'Connell M, McNally C, Richardson M. Biochemical attack on concrete in wastewater applications: a state of the art review. Cem Concr Compos 2010; 32(7):479-85

[3] Yan L, Chouw N. Behavior and analytical modeling of natural flax fibre reinforced polymer tube confined plain concrete and coir fibre reinforced concrete. J Compos Mater, in press.

[4] Hollaway LC. Key issues in the use of fibre reinforced polymer (FRP) composites in the rehabilitation and retrofitting of concrete structure. In: Karbhari VM, Lee LS, editors. Service life estimation and extension of civil engineering structures. Abington Hall, Cambridge: Woodhead Publishing Limited; 2011

[5] Mora E. Life cycle, sustainability and the transcendent quality of building materials. Build Environ 2007;42:1329-34

[6] Delatte N. Introduction. In: Delatte N, editor. Failure, distress and repair of concrete structure. Abington Hall, Cambridge: Woodhead Publishing Limited; 2009.

[7] Davidovits J. Synthesis of new high temperature geo-polymers for reinforced plastics/composites. SPE PACTEC 79 society of plastic engineers, Brookfield Center. p. $151-4$

[8] Davidovits J. Geopolymer chemistry and sustainable development. The Poly(sialate) terminology: a very useful and simple model for the promotion and understanding of green-chemistry. In: Proceedings of 2005 geopolymer conference vol. 1. p. 9-15.

[9] Xu Hua, Van Deventer JSJ. The geopolymerisation of alumino-silicate minerals. Int J Miner Process 2000;59:247-66.

[10] Barbosa Valeria F, MacKenzie KJD, Thaumaturgo Clelio. Synthesis and characterisation of materials based on inorganic polymers of alumina and sílica: sodium polysialate polymers. Int J Inorg Polym 2000;2:309-17.

[11] Vance E, Perera D. Geopolymers for nuclear waste immobilisation. In: Provis J, Van Deventer J, editors. Geopolymers, structure, processing, properties and applications. Abington Hall, Cambridge, UK: Woodhead Publishing Limited 2009. p. 401-20.

[12] Vinsova H, Jedinakova-Krizova, Gric L, Sussmilch J. Immobilization of toxic contaminants into aluminosilicate matrixes. Proceedings of the 2007 - alkali activated materials - research, production and utilization 3rd conference, 735736. Prague, Czech Republic: Agentura Action; 2007.

[13] Provis J. Immobilisation of toxic wastes in geopolymers. In: Provis J, Van Deventer J, editors. Geopolymers, structure, processing, properties and applications. Abington Hall, Cambridge, UK: Woodhead Publishing Limited; 2009. p. 421-40 [ISBN-13: 9781845694494 ].

[14] Bakharev A. Geopolymeric materials prepared using class F fly ash and elevated temperature curing. Cem Concr Res 2005;35:1224-32.

[15] MacKenzie KJD, Brew D, Fletcher R, Nicholson CL, Vagana R, Schmucker M Towards an understanding of the synthesis mechanisms of geopolymer materials. In: Proceedings of the world geopolymer, geopolymer green chemistry and sustainable development, solutions; 2005. p. 41-4.

[16] Fernandez-Jimenez A, Palomo A. Composition and microstructure of alkali activated fly ash binder: effect of the activator. Cem Concr Res 2005;35: 1984-92.

[17] Bakharev T. Geopolymeric materials prepared using class $\mathrm{F}$ fly ash and elevated temperature curing. Cem Concr Res 2005;35:1224-32.
[18] Weng L, Sagoe-Crentsil K, Brown T, Song S. Effects of aluminates on the formation of geopolymers. Mater Sci Eng 2005;117:163-8.

[19] Yip CK, Van Deventer SJS. Microanalysis of calcium silicate hydrate gel formed within a geopolymeric binder. J Mater Sci 2003;38:3851-60.

[20] Yip CK, Lukey GC, Van Deventer SJS. The coexistence of geopolymeric gel and calcium silicate hydrate gel at the early stage of alkaline activation. Cem Concr Res 2005;35:1688-97.

[21] Buchwald A, Dombrowski K, Weil M. The influence of calcium content on the performance of geopolymeric binder especially the resistance against acids. In: Proceedings of the world geopolymer 2005, geopolymer green chemistry and sustainable development, solutions; 2005. p. 35-9.

[22] Wu Hwai-Chung, Sun Peijang. New building materials from fly ash-based lightweight inorganic polymer. Constr Build Mater 2005;21:211-7.

[23] Duxson P, Provis J, Luckey G, Van Deventer J. The role of inorganic polymer technology in the development of "Green Concrete". Cem Concr Res 2007;37: 1590-7.

[24] Provis JL, Muntingh Y, Lloyd RR, Xu H, Keyte LM, Lorenzen L, et al. Will geopolymers stand the test of time? Ceram Eng Sci Proc 2008;28:235-48.

[25] Kani E, Allahverdi A, Provis J. Efflorescence control in geopolymer binders based on natural pozzolan. Cem Concr Compos 2011;34:25-33.

[26] Weil M, Dombrowski K, Buchawald A. Life-cycle analysis of geopolymers. In: Provis J, Van Deventer J, editors. Geopolymers, structure, processing, properties and applications. Abington Hall, Cambridge, UK: Woodhead Publishing Limited; 2009. p. 194-210.

[27] Habert G, de Lacaillerie J, Roussel N. An environmental evaluation of geopolymer based concrete production: reviewing current research trends. J Cleaner Prod 2011;11:1229-38.

[28] Bai J. Durability of sustainable concrete materials. In: Khatib J, editor. Sustainability of construction materials. Abington Hall, Cambridge: Woodhead Publishing Limited; 2009. p. 239-53.

[29] Bijen J. Durability of engineering structures. Design, repair and maintenance. Abington Hall, Cambridge: Woodhead Publishing Limited; 2000.

[30] Medeiros M, Helene P. Efficacy of surface hydrophobic agents in reducing water and chloride ion penetration in concrete. Mater Struct 2008;41: 59-71.

[31] Balaguru P. Geopolymer for protecting coating of transportation infrastructures. Center for advanced infrastructure and transportation (CAIT). Civil \& environmental engineering. Piscataway: Rutgers State University; 2002.

[32] Papakonstantinou CG, Balaguru PN. Geopolymer protective coatings for concrete. International SAMPE symposium and exhibition (proceedings), vol. $52 ; 2007$.

[33] Balaguru P, Nazier M, Arafa M. Field implementation of geopolymer coatings. Center for advanced infrastructure and transportation (CAIT). Civil \& environmental engineering. Piscataway: Rutgers State University; 2008.

[34] Zhang Z, Yao X, Zhu H. Potential applications of geopolymers as protection coatings for marine concrete I. Basic properties. Appl Clay Sci 2010;49: $1-6$.

[35] Zhang Z, Yao X, Zhu H. Potential application of geopolymers as protection coatings for marine concrete II. Microstructure and anticorrosion mechanism. Appl Clay Sci 2010;49:7-12.

[36] Emmons P, Vaysburd A. Factors affecting the durability of concrete repair: the contractor's viewpoint. Constr Build Mater 1994;8:5-16.

[37] Emmons P, Vaysburd A. Total system concept - necessary for improving the performance of repaired structures. Constr Build Mater 1996;10:69-75.

[38] Morgan D. Compatibility of concrete repair materials and systems. Constr Build Mater 1996;10:57-67.

[39] Murray M. Patching of deteriorated concrete structures. In: Delatte N, editor. Failure, distress and repair of concrete structure. Abington Hall, Cambridge: Woodhead Publishing Limited; 2009. p. 282-95.

[40] Pacheco-Torgal F, Gomes J, Jalali S. Adhesion characterization of tungsten mine waste geopolymeric binder. Influence of OPC concrete substrate surface treatment. Constr Build Mater 2008;22:154-61.

[41] Fukuyama H, Sugano S. Japanese seismic rehabilitation of concrete building after the hyogoken nanbu earthquake. Cem Concr Compos 2000;22(1):59-79.

[42] American Concrete Institute (2000) Guide for design and construction of externally bonded FRP systems for strengthening concrete structures, ACI Committee 440. Farmington Hills, Michigan, USA; 2000.

[43] Badanoiu A, Holmgren J. Cementitious composites reinforced with continuous carbon fibres for strengthening of concrete structures. Cem Concr Compos 2003;25:387-94.

[44] American Concrete Institute (1997) Guide for application of epoxy adhesives for bonding freshly mixed and hardened concretes, ACI Committee 503. Farmington Hills, Michigan, USA; 1997.

[45] Gamage J, Al-Mahaidi R, Wong M. Bond characteristics of CFRP plated concrete members under elevated temperatures. Compos Struct 2006;75:199-205.

[46] Aguiar J, Camões A, Vaz N. Effect of temperature on RC elements strengthened with CFRP. Mater Struct 2008;41:1133-42.

[47] Vasconcelos E, Fernandes D, Barroso de Aguiar JL, Pacheco Torgal F. Concrete retrofitting using metakaolin geopolymers mortars and CFRP. Constr Build Mater 2011;25:3213-21.

[48] Okabe S, Odagiri M, Ito T, Satoh H. Succession of sulfur-oxidizing bacteria in the microbial community on corroding concrete in sewer systems. Appl Environ Microbiol 2007;73:971-80.

[49] Garcia C, Abraham DM, Gokhale S, Iseley T. Rehabilitation alternatives for concrete and brick sewers. Pract Periodical Struct Des Constr 2002;7:164-73. 
[50] Najafi M. Pipeline rehabilitation for service life extension. In: Karbhari VM, Lee LS, editors. Service life estimation and extension of civil engineering structures. Abington Hall, Cambridge: Woodhead Publishing Limited; 2011. p. $262-89$.

[51] Burtner R, Howard A, Sung T, Stahl J. Rehabilitation of a large semi-elliptical sewer. Water Environment Foundation. WEFTEC 2006.

[52] Pacheco Torgal F, Jalali S. Toxicity of building materials. A key issue in sustainable construction. Int J Sustain Eng 2011:4:281-7.

[53] Pacheco-Torgal F, Jalali S, Fucic A. Toxicity of building materials. Cambridge: Woodhead Publishing Limited; 2012.

[54] Davidovits J, Comrie DC, Paterson JH, Ritcey DJ. Geopolymeric concretes for environmental protection. ACI Concr Int 1990;12:30-40.
[55] Gourley JT, Johnson GB. Developments in geopolymer precast concrete. Proc of geopolymer 2005 world congress, 139-143. S. Quentin, France: Geopolymer Green Chemistry and Sustainable Development Solutions; 2005.

[56] Pacheco Torgal F, Gomes J, Jalali S. Durability and environmental performance of alkali-activated tungsten mine waste mud mortars. J Mater Civ Eng 2010;22:897-904.

[57] Allouche E, Montes C, Diaz E. A new generation of cementitious materials for mortar lining of buried pipes. Pipelines 2007: advances and experiences with trenchless pipeline projects - proceedings of the ASCE international conference on pipeline engineering and construction; 2007.

58] Montes C, Allouche E. Evaluation of the potential of geopolymer mortar in the rehabilitation of buried infrastructure. Struct Inf Eng 2012;8:89-98. 